THE INTERNATIONAL ASSOCIATION OF CHEMICAL SOCIETIES.

THE science of chemistry has some 20,000 1 adherents at least. Chemical journals are very numerous, and it would be impossible for any one man to read current chemical literature, were he to read for twenty-four hours a day. The investigations of chemists are published, for the most part, in transactions of chemical societies, and until recently these societies lived apart, having merely a bowing acquaintance with one another. "Union is strength," and in default of union, cooperation lends a strengthening hand. Hence a proposal which originated in the winter of I9IO-II with Profs. Ostwald and Haller to form an association of chemical societies was regarded with favour by the three great chemical societies of London, Berlin, and Paris.

To organise this association, a preliminary meeting was held in Paris in April, I9I I, at which were present three Frenchmen, MM. Béhal, Haller, and Hanriot; three Germans, Herren Jacobson, Ostwald, and Wichelhaus; and two Englishmen, Dr. Percy Frankland and Sir William Ramsay, as delegates of the three national societies. It was there resolved that all chemical societies should have the right to demand admission to the association, provided their proceedings were published in a journal; and also that each country should be represented by only one society.

At this meeting, too, questions in regard to which the association might do useful work were indicated. Among these are: Nomenclature and classification of chemical compounds; atomic weights; the unification of the notation of physical constants; the editing of indices and summaries of chemical work; consideration of the possibility of utilising a universal language; unification of the size of pages of chemical literature; means to be taken to prevent the re-publication of papers in different journals; and publication of a complete record of chemistry. Statutes were also drawn up; the object of the association is defined as "forming a link between the chemical societies of the world, which shall deal with questions of general and international importance for chemistry." The constitution of the council is also defined in the statutes; there shall be a president, a vice-president, and a secretary, chosen from the same nation, who shall be an acting committee for the period of one year.

During this preliminary meeting, the chair was occupied by each delegate in succession; but Prof. Ostwald was elected president for the meeting in 19r2, Prof. Wichelhaus, vice-president, and Prof. Jacobson secretary.

In April, 1912, the first statutory meeting was held in Berlin. The Swiss Chemical Society had joined in the meantime, and was represented by MM. Fichter, Guye, and Werner; the American Chemical Society, by Prof. W. A. Noyes; and the Russian Chemical Society, by MM. Kurnakow, Tschugaeff, and Walden; while M. Marie represented the Société de Chimie-physique of Paris;
Hr. Auerbach, the Bunsen-Gesellschaft; Prof. Cohen the Netherland Chemical Union; Hr. Goldschmidt, the Norwegian; and Hr. Biilmann, the Danish Chemical Society. The Italian societies, although they had applied and been received as members of the association, were unrepresented on this occasion.

At the first meeting in Berlin, Great Britain was chosen as the next place of meeting; and Sir William Ramsay was chosen to be president, Prof. Frankland vice-president, and Prof. Crossley was subsequently appointed secretary.

During the meeting the projects suggested were further discussed, and committees were appointed to consider and report on nomenclature, on abbreviated titles for chemical journals, on the size of pages of journals, and on means to overcome the difficulties caused by a multiplicity of languages. It was also announced that the chemical societies of Madrid and of Tokyo, and the Union of Austrian Chemists had applied for admission to the Association. It was arranged that the meeting in $\mathrm{rgr}_{3}$ should take place in England in August or September, so as to suit the convenience of American chemists.

This resolve, however, was changed, for the following reason. M. Ernest Solvay, the great Belgian chemical manufacturer, declared his intention of assisting this international movement by a large donation. Hitherto, the expenses had been defrayed by the participating societies. But M. Solvay informed the officers that he wished to place unreservedly at the disposal of the association a sum of 250 ,000 francs, and that he desired also to set apart a sum of $\mathrm{r}, 000,000$ francs, under such conditions that the capital would be exhausted in twenty-nine years. $\mathrm{He}$ ear-marked one-third of the interest of this sum to be devoted to scholarships for Belgian students, while the remaining two-thirds were to be placed at the disposal of the association. This fund is to be administered by a commission, consisting so far as the scholarships are concerned, of M. Solvay himself, or his nominee; of a member nominated by H.M. the King of the Belgians; and lastly, by a member nominated by the University of Brussels. These members, together with three representatives of the council of the association, viz., MM. Haller and Ostwald, and Sir W. Ramsay, are directors of an "International Institute of Chemistry." M. Solvay also signified his intention to provide the association with a secretariat at Brussels, which should serve as a permanent abode.

It was therefore thought advisable to abandon the intention of meeting in England, and to hold the meeting for $19{ }^{1} 3$ in Brussels, so as to have an opportunity of thanking Monsieur Solvay for his generous gift. A further reason for meeting in Brussels lay in the fact that the days appointed coincided with the date of M. Solvay's golden wedding, as well as the fiftieth anniversary of the foundation of the industry which bears his name. The date was accordingly September 19 to 23 .

At this meeting the Chemical Society of Belgium was represented; there were present besides 
delegates from Germany, England, Austria, Denmark, Spain, France, Holland, Italy, Norway, Russia, and Switzerland; the United States and Japan were unrepresented. In all, seventeen chemical societies are affiliated to the international association, representing nearly 20,000 members. Much valuable assistance was received from $M$. Tassel and from M. Heger in arranging for the meetings.

It was agreed that the place of meeting for rgr 4 should be Paris, with M. Haller as president. The business done at the Brussels meeting was satisfactory; steps were taken to affiliate the committee on atomic weights; to unify the methods of abbreviating the names of journals; to secure publication of important memoirs which have appeared in one of the less known languages in English, French, or German; to open negotiations to diminish the multiplicity of abstracts, by cooperation among the various bodies which publish extracts; and some important resolutions dealing with nomenclature, and with symbols for physical constants, were adopted.

The need of such an association has now been amply shown. Much can be done to simplify methods, and, by cooperation, to diminish labour, and increase convenience. There is still much to be done, however, and the usefulness of the association will doubtless survive the period at which Monsieur Solvay's gift will be exhausted. The assembling of chemists from various nations, with free interchange of ideas, cannot fail to stimulate all working at the science of chemistry, and cannot fail to promote cordial international relations. "La Science est sans patrie!"

William Ramsay.

\section{HEALTH IN INDIA.}

T NDER the title, "A Modern Miracle," The Pioneer Mail of September 12 gives some striking figures of the improvement of health among the European troops in India-these figures being taken from the Army Medical Report for last year. With a strength of more than 7I, ood British troops in India, there were positively only 328 deaths during the year, equal to $4^{\cdot 62}$ per Iooo. This is really a remarkable achievement; and the smallness of the death-rate is not due in any way to an increase in the invaliding to England-as shown by the fact that the invaliding also fell markedly during the year to 6.68 per rooo, compared with 23 per rooo in 1892 . These are by far the lowest rates on record, and are comparable with the great decrease in the death-rate and the invaliding among non-native officials in West Africa, as disclosed by recent Colonial Office Reports.

Enteric fever, which was once such a terrible pest in India, has now decreased so much that there were only i 18 admissions to hospital for it among the whole British garrison. This is undoubtedly due partly to the very great care now exercised in dealing with potential carriers of the disease, both human carriers and flies, and also to anti-typhoid inoculation. Malaria also has shown a very marked decrease during the year, though, as The Pioneer Mail points out, this may possibly be partly due to the usual fluctuations in the prevalence of the disease caused by variations in climate. Cholera and plague have also diminished.

Those who are interested in the subject would do well to compare with this fine record a remarkable paper by Sir Charles Pardey Lukis, DirectorGeneral of the Indian Medical Service, in the October number of Science Progress, entitled "The Sanitary Awakening of India." Sir Pardey Lukis describes the whole position of sanitation in India, and also the very extensive advances which are now being made in the investigation of disease, and the practical application of preventive measures there. Since he has occupied his important post, energy has been redoubled in all these directions. The whole Indian Medical Service, and the Officers of the Royal Army Medical Corps now serving in India, must all be heartily congratulated for the splendid work which they are now doing. Of course, there are ideals still before us; but the old apathy which used to exist in many quarters seems now to be a thing of the past.

Vaccination in India is also doing extremely well. Nearly two million vaccinations were performed in the Bengal Presidency alone during I912-13, and the total number of deaths from smallpox in that Presidency during the year was only $0^{\circ} 2 \mathrm{I}$ per thousand of the population-a very good figure for a country where vaccination has been much opposed on account of "religious" scruples. The lanoline lymph, which I believe was originally invented by Colonel King, is principally responsible for this good state of affairs, and Colonel King is to be much congratulated upon it.

Ronald Ross.

\section{THE PROBLEM OF THE UNIVERSITY OF LONDON.}

SINCE the article in our issue of December I I - was written, further events of importance have taken place. We referred in that article to the proposal of the Higher Education Sub-Committee of the London County Council to recommend the London County Council to invite the Senate of the University of London to express approval of Somerset House as a place for the further development of the University. The recommendation in favour of this site was adopted by the Council at Tuesday's meeting, after discussion. The Council agreed, without a division, to an amendment proposing that, if the Government could not consent to the Somerset House suggestion, the Education Committee should be instructed to report on the proposal to establish the university on a site on the south bank of the river, "where it would form an important feature in the beautifying of London." This proposal has something to be said for it from the point of view of the improvement of 